\title{
The Relationship between Information Systems Strategic Management Based on Balanced Scorecard and Information Systems Performance
}

\author{
Maryam Ebrahimi ${ }^{1}$, Alireza Hassanzadeh ${ }^{1}$, Shaban Elahi $^{1}$ \& Mahshid Ebrahimi ${ }^{2}$ \\ ${ }^{1}$ School of Business and Economics, Tarbiat Modares University, Tehran, Islamic Republic of Iran \\ ${ }^{2}$ School of Management, University of Tehran, Tehran, Islamic Republic of Iran \\ Correspondence: Maryam Ebrahimi, School of Business and Economics, Tarbiat Modares University, PO Box \\ 14115-111, Jalal Ale Ahmad Highway, Tehran, Islamic Republic of Iran. Tel: 98-21-8806-3104. E-mail: \\ mar.ebrahimi@gmail.com
}

Received: April 15, 2013

Accepted: June 26, 2013

Online Published: July 2, 2013

doi:10.5430/ijba.v4n4p35

URL: http://dx.doi.org/10.5430/ijba.v4n4p35

\begin{abstract}
In the present study, the model of information technology balanced scorecard (ITBSC) was used, because of the importance of information systems (IS) performance evaluation. Moreover, information systems strategic management based on systems performance was considered in order to formulate the information systems strategy based on the results of the systems performance. The information systems strategic management was analyzed on the basis of balanced scorecard maturity model. The research aims to answer this question that "is there any significant relationship between information systems strategic management based on balanced scorecard and information systems performance?" To do this, a sample group including 30 organizations in Tehran - the capital city of Iran was selected and the maturity status of IT balanced scorecard and the performance degree of their information systems were studied. It was concluded that increase (decrease) in the level of information systems strategic management based on balanced scorecard cause to increase (decrease) in performance of information systems and vice versa.
\end{abstract}

Keywords: balanced scorecard, strategic management, IT, information system

\section{Introduction}

Nowadays, the growth of IT role in achieving organizational goals brings some questions into mind about effectiveness of IT department of the organization, success of IT programs and profitability of investments in different IT areas. It shows that all organizations are involved in measuring value of IT and assessment of information systems performance (Martinsons et. al., 1999).

Lee and Menon (2000) insisted on the positive relationship between investment on IT and organization productivity. In addition to productivity, investment on IT has made a great value for customers (Mingfang and Richard Ye, 1999). Shao and Lin (2001) have discussed about the positive effect of information technology on technical efficiency of production processes.

Despite of its benefits, a sense of dissatisfaction has been created about investment on IT some of which was because of limitations in defining measurement criteria for the value added to the organization by IT (Stewart and Mohamed, 2003).

It is very difficult and complicated to measure benefit of IT. Keen (1991) has introduced some reasons for this complexity.

1) Investment on the IT field usually doesn't lead to benefit directly. Similar to research and development and human resources management, the benefits of IT are rarely related to obvious costs of the same area in a direct way. The benefits resulted from such investment is not easily recognizable, especially when investments are made in areas such as organizational effectiveness and culture.

2) The same amount of investment on the same technology may cause to different results, as it is the management processes in the organization that indicate quality and quantity of achieved benefits through technology.

3) In traditional accounting system, many benefits and added values resulting from IT are not showed. 
Typically, investing on IT is related to organization strategy and the relationship between IT and organizational performance should be studied in the strategic management framework (Bharadwaj et. al., 1993; Sircar et. al., 1998; Balanced Scorecard Institute, 2004).

Assessment of IT performance depends on its true execution. There are several methods of assessing IT performance some of which are rate of return on investment, net present value, etc. But since it is necessary for IT to be in line with the business, consistent control and assessments and regarding intangible capitals, the balanced scorecard of IT is used to assess IT performance in the present study, and then, a comprehensive model for IT balanced scorecard extracted from existing researches is delivered (Martinsons et. al., 1999; Stewart and Mohamed, 2003; Epstein and Rejc, 2005; Kaplan and Norton, 1993, 1996, 1996, 2004; Martinsons, 1992; Stewart, 2002, 2007; Watts, 2003; Van Grembergen and Saul, 2001; Van Grembergen, 2000; Van Grembergen and Van Bruggen,1997; Van Grembergen et. al., 2003).

Additionally, the balanced scorecard performance management tool has been offered by Kaplan and Norton (1996) as "...the cornerstone of a new strategic management system..." (Atkinson, 2006). In the other words, the strategic management of information systems is needed to make a strategic advantages of information systems and the alignment of investments on IT and organization strategy. In addition, strategy formulating of information systems based on the results of information systems performance causes to always-up-to-date strategies. Therefore, the present study about strategic management of information systems considers the performance of information systems and analyzes information systems strategic management based on balanced scorecard through using the balanced scorecard maturity model (Luftman, 2001).

\section{Problem Statement}

Investment on IT is broadly developing and in the same time, the managers concern whether the advantages will be as expected. This is called the paradox of investment on IT or black hole of IT. In the other words, bulk money is expensed for IT, whereas it is expected that the bulk money is swallowed by the big black hole without any value return. The IT/ information systems balanced scorecard is utilized amongst other methods of measuring IT.

There are two different presumptions in researches made until now about the balanced scorecard which are as follow (Ghaeni, 2006):

1) Similar to total quality management (TQM), the balanced scorecard as a measurement instrument follows improvement of organization performance.

2) The balanced scorecard as a strategic management instrument using which the organization tries to remove obstacles in the way of executing the organizational strategy such as translating organizational strategy to goals.

Until now and regarding the existing researches, the balanced scorecard is viewed more as a performance measurement instrument, whereas it can also be an instrument of strategic management in each industry, even IT industry. Despite existing researches, this study is to view the balanced scorecard from both aspects, especially in IT industry which differs from other industries by difficulty of its effectiveness control.

The present study aims to answer this question that "is there any significant relationship between information systems strategic management based on balanced scorecard and information systems performance?" On this basis, the hypothesis of the research is as follows: "there is a significant relationship between information systems strategic management based on balanced scorecard and the performance of information systems.

"Information systems strategic management based on balanced scorecard" and "information systems performance" are two variable of the research. To study strategic management of information systems, the model of balanced scorecard maturity was used. Also, the model of comprehensive balanced scorecard of IT was utilized for studying information systems performance.

\section{Theoretical Basics of the Research}

The framework of the IT balanced scorecard is structurally similar to the model introduced by Kaplan and Norton. Although this model with four aspects: financial, internal processes, customer satisfaction and growth and learning, has been judged suitable in different companies and industries, these four aspects should merely be considered as a primary framework, not a general one. In the other words, these aspects should be adopted according to situation and special activities of IT (khanlari \& mohammadi, 2006).

In this paper, to propose a comprehensive model including aspects and indicators for assessment of information systems performance, several models have been studied. In the proposed model, four aspects as financial, internal processes, user satisfaction, and growth and learning were used which are based on primary framework presented by 
Kaplan and Norton and existing models.

Epstein and Rejc, 2005, indicate goals and criteria for the IT balanced scorecard as following figure:

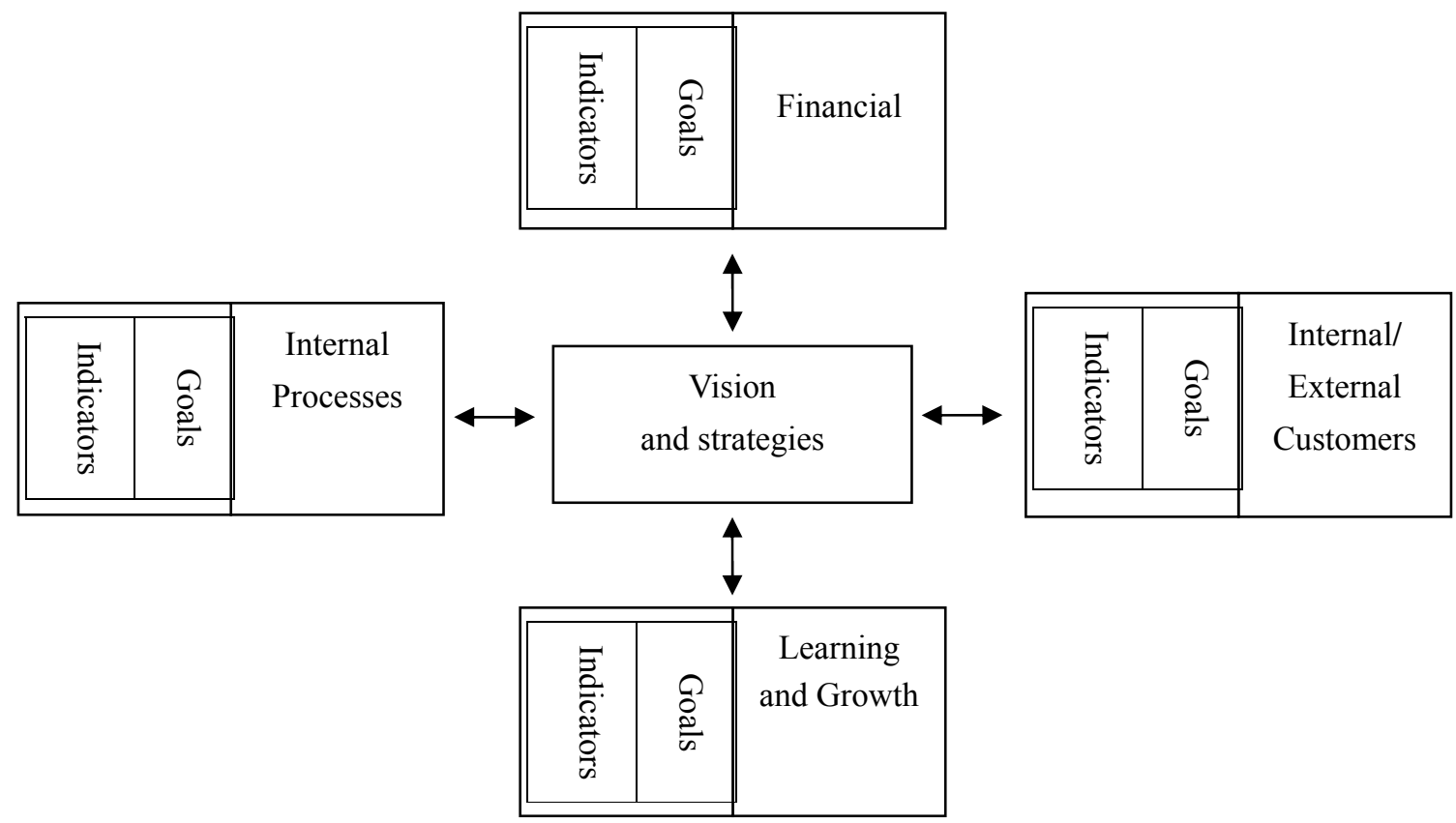

Figure 1. IT balanced scorecard (Epstein and Rejc, 2005)

Four aspects of the IT balanced scorecard are as follows:

a) Financial: financial indicators are very important in most organizations. Such organizations struggle to increase income, to decrease costs and risks, to use of properties most-effectively and boost the productivity (Kaplan and Norton, 1993, 1996, 1996, 2004). In this model, the goal of financial aspect is profitability and includes following indicators: the percentage of changes in stock price through IT initiations, the income growth and the percentage of total decrease of costs (Epstein and Rejc, 2005).

b) Customer: the managers must be aware of this issue- whether the organization can satisfy its customers' needs. To do this, all value transferring to the customer should be indicated and measured (Kaplan and Norton, 1993, 1996, 1996, 2004). In this model, customers are divided into two groups: internal and external. The internal customer is used in circumstance in which the organization refers to its departments or divisions to receive some IT services. Customer loyalty, adding value, absorbing customer, improving quality and increasing productivity are goals of this aspect which consist of indicators such as: customer's profit average, profit resulting from IT projects, customer satisfaction from IT activities, customer longevity percentage, the percentage of new visitors who revisit, the percentage of returning customer for revisiting the website, the number of customers absorbed via IT innovations, the percentage of website visitors who make a purchase too, the number of cooperation with the customer, the percentage of saving because of redundancy reduction, the percentage of reducing customers' complains, the percentage of saving because of quality improvement, the percentage of increase in customer's processed orders and the percentage of increase in the rate of production in respect of personnel (Epstein and Rejc, 2005).

c) Internal processes: measuring the degree of value producing and the way of relating processes can help managers to understand the works. Thus, it is necessary to identify the processes which are required to achieve the goals related to customers, shareholders, etc. and to investigate them (Kaplan and Norton, 1993, 1996, 1996, 2004). Improving processes, products and services of IT, increasing security, standardizing IT infrastructures and return of the resources are goals of this aspect which consist of indicators such as: the number of new presented products and services, the average time required for answering customers' requests via IT, the percentage of information systems failures, the number of applications not completely integrated with the whole system, the percentage of standardization of the software, databases and applications, and the percentage of return of IT costs dedicated to company units (Epstein and Rejc, 2005).

d) Growth and learning: capability of an organization for innovation, improvement and learning is directly connected 
to its value as an organization. An organization can get growth and innovation only when it is able to develop its skills and leadership, get the lessons of its and other organizations' faults and mistakes and establish its own new methods (Kaplan and Norton, 1993, 1996, 1996, 2004). Measuring the performance and development of skills and knowledge of IT personnel are the goals of this aspect which consist of indicators such as: the percentage of assessing projects according to the rate of return on investment, the percentage of IT personnel who gets rewards based on performance, the percentage of documented and measured IT processes, the percentage of investments on skills and knowledge of IT personnel, stability of IT personnel and the proportion of IT professionals in respect of personnel (Epstein and Rejc, 2005).

In addition to strategy, Martinsons et. al., 1999; Martinsons, 1992, suggests in its proposed information systems balanced scorecard, four aspects of "business value", "internal processes", " future readiness" and " user orientation". The "business value" aspect which is to increase business value, achieve organization goals and such goals as gaining management commitment and controlling costs of information systems, includes criteria entitled as "cost control", "risk control" and "IT value". These criteria respectively consist of indicators such as: IT-based products and services income, inability for interacting IT departments with other departments of the organization, the problems of interacting between human beings and computer, the percentage of time spent by IT division with executive managers and finally IT in the mind of managers.

Also, the "internal processes" aspect consists of three criteria of "planning", "developing" and "implementing" which respectively mean the percentage of resources dedicated to planning and reviewing of information systems activities, development of applications and resolving users' problems. The aspect of "future readiness" consists of two criteria of capability of information systems experts and researches on modern technologies which include the budget of teaching and researching in IT area. The "user's orientation" means to create and retain relationship with users, satisfying user's information requirements and the effect of information systems on efficiency and effectiveness increase (Martinsons et. al., 1999; Martinsons, 1992).

In addition to strategy, Stewart and Mohamed, 2003; Stewart, 2002, 2007, suggests in its information systems balanced scorecard, four aspects briefly as follows: "operational perspective" which insists on the effect of IT on productivity, e.g. the effect of IT on improving processes, communications and decision making. "Benefits perspective" which considers the relationship between implementation of IT and tangible (monetary) and intangible (non-monetary) benefits e.g. saving money and time. "System/technology perspective" which refers to performance, reliability, accessibility, security of system/technology and analogy between applications and processes. And finally "user orientation perspective" which consists of using technology, teaching, technical support and satisfaction with IT.

In addition to strategy, Watts, 2003, suggests in its information systems balanced scorecard, four aspects as below: "financial" aspect such as: estimated costs for IT projects against actual costs or estimated benefits of IT projects against actual benefits; "customer" aspect such as customer satisfaction with benefits of IT projects; "internal processes" such as the percentage of sources which are dedicated to IT support; "growth" aspect indicates e.g. contractor personnel vs. official permanent personnel, the management staff to total employees, and the education time.

In addition to strategy, Van Grembergen and Saul, 2001; Van Grembergen, 2000; Van Grembergen and Van Bruggen, 1997; Van Grembergen et. al., 2003, suggest in the information systems balanced scorecard, four aspects as follows: "corporate contribution" with such goals as reaching value of IT projects, managing investments on IT; "customer orientation" with such goals as cooperation of IT division with other divisions of the organization, improvement of information systems and services performance; "future orientation" aiming to staff management effectiveness, organization architecture upgrade and access to modern technologies; and "operational excellence" aiming to the best processes.

Therefore, it is possible to indicate general criteria for evaluating IT performance as shown in Tables 1 and 2. 
Table 1. The IT balanced scorecard proposed in the present research

\begin{tabular}{|c|c|c|c|c|}
\hline Financial & \multicolumn{2}{|l|}{ Source } & User satisfaction & Source \\
\hline $\begin{array}{l}\text { mission: increasing business value } \\
\text { and achieving organization goals }\end{array}$ & \multicolumn{2}{|l|}{ Martinsons et. al., 1999} & $\begin{array}{l}\text { Mission: providing products } \\
\text { and services in accordance }\end{array}$ & Martinsons et. al., 1999 \\
\hline Goals: $\quad$ Gaining managers' & \multicolumn{2}{|l|}{ Martinsons et. al., 1999} & with users' requirements & \\
\hline commitment & \multirow{2}{*}{\multicolumn{2}{|c|}{ Martinsons et. al., 1999}} & Goals: Establishing and & (Martinsons et. al., \\
\hline Controlling IS costs & & & maintaining satisfactory & Epstein and Rejc, 2005) \\
\hline Managing IT investments & Grembergen and & Saul, & relationship with users & \\
\hline \multirow[t]{4}{*}{ Earning profit } & \multirow{2}{*}{\multicolumn{2}{|c|}{ Epstein and Rejc, 2005}} & & \\
\hline & & & Gaining users' commitment & Martinsons et. al., 1999 \\
\hline & & & $\begin{array}{l}\text { Participation between business } \\
\text { and IT }\end{array}$ & Grembergen and Saul, 2001 \\
\hline & & & Improving IS performance & $\begin{array}{l}\text { (Grembergen and Saul, 2001; } \\
\text { Epstein and Rejc, 2005) }\end{array}$ \\
\hline Internal processes & \multicolumn{2}{|l|}{ Source } & Growth and learning & Source \\
\hline $\begin{array}{l}\text { Mission: creating, delivery and } \\
\text { maintaining IT products and services } \\
\text { effectively and efficiently }\end{array}$ & \multicolumn{2}{|l|}{ Martinsons et. al., 1999} & $\begin{array}{l}\text { Mission: } r \text { consistent } \\
\text { improvement and getting ready } \\
\text { to come across future }\end{array}$ & Martinsons et. al., 1999 \\
\hline $\begin{array}{l}\text { Goals: Increasing efficiency of } \\
\text { planning, developing, implementing } \\
\text { and maintaining IS }\end{array}$ & \multicolumn{2}{|l|}{ Martinsons et. al., 1999} & $\begin{array}{l}\text { challenges } \\
\text { Goals: Getting ready to come } \\
\text { across IS problems }\end{array}$ & Martinsons et. al., 1999 \\
\hline $\begin{array}{l}\text { Cost-effective training to satisfy } \\
\text { training needs of users }\end{array}$ & \multicolumn{2}{|l|}{ Martinsons et. al., 1999} & $\begin{array}{l}\text { Consistent improvement of } \\
\text { staffs' skills through training }\end{array}$ & $\begin{array}{l}\text { (Martinsons et. al., } 1999 \text {; } \\
\text { Epstein and Rejc, 2005) }\end{array}$ \\
\hline \multirow[t]{4}{*}{ Managing non-completed works } & \multirow[t]{4}{*}{$\begin{array}{l}\text { Grembergen and } \\
2001\end{array}$} & \multirow[t]{4}{*}{ Saul, } & $\begin{array}{l}\text { Improvement of services } \\
\text { capability (internal processes, } \\
\text { technology renewal) }\end{array}$ & Grembergen and Saul, 2001 \\
\hline & & & Effective staff management & Grembergen and Saul, 2001 \\
\hline & & & $\begin{array}{l}\text { Organization } \\
\text { improvement }\end{array}$ & Grembergen and Saul, 2001 \\
\hline & & & $\begin{array}{l}\text { Achieving } \\
\text { technologies }\end{array}$ & Grembergen and Saul, 2001 \\
\hline
\end{tabular}


Table 2. Indicators for the IT balanced scorecard proposed in the present research

\begin{tabular}{|c|c|c|c|}
\hline Financial & Source & User satisfaction & Source \\
\hline 1. cost control & (Martinsons et. al., 1999) & 1. establishing and & (Martinsons et. al., 1999) \\
\hline The ratio of IT costs to company costs & (Watts, 2003) & relationship with users & \\
\hline The ratio of estimated costs to actual costs & (Watts, 2003) & The degree of cooperation of IT unit with & (Grembergen and Saul, 2001 \\
\hline The ratio of Estimated advantages to actual & (Watts, 2003) & the customer & Epstein and Rejc, 2005 ) \\
\hline advantages & & The number of website visitors & (Epstein and Rejc, 2005) \\
\hline Income resulting from IT-based products and services & (Martinsons et. al., 1999) & The number of customers absorbed through & (Epstein and Rejc, 2005) \\
\hline The percentage of total decrease of costs & (Epstein and Rejc, 2005) & IT innovations & \\
\hline 2. risk control & (Martinsons et. al., 1999) & 2. satisfaction degree & \\
\hline the inability degree to integrate business and IT units & (Martinsons et. al., 1999) & Comparing customers satisfaction & (Grembergen and Saul, 2001) \\
\hline the difficulty level of the interaction between human & (Martinsons et. al., 1999) & respecting before & \\
\hline beings and computer & & Satisfaction degree from IT training & (Stewart and Mohamed \\
\hline the degree of using inappropriate hardware and & (Martinsons et. al., 1999) & & 2003) \\
\hline software & & Satisfaction degree from IT support & (Stewart and Mohamed \\
\hline the percentage of time spent by IS managers in & (Martinsons et. al., 1999) & Satisfaction degree from IT projects & (Watts, 2003) \\
\hline meetings with executive managers & & enefits & \\
\hline evaluating accountability to customer & (Martinsons et. al., 1999) & Satisfying user's requirements & (Martinsons et. al., 1999) \\
\hline quality of services and products & (Martinsons et. al., 1999) & & \\
\hline evaluating the degree of innovation & (Martinsons et. al., 1999) & 3. performance level & \\
\hline managers' understanding of IS & (Martinsons et. al., 1999) & the degree of performance improvement of & (Grembergen and Saul, 2001) \\
\hline & & $\begin{array}{l}\text { IS and the quality presented (time and } \\
\text { budget) }\end{array}$ & \\
\hline & & the level of services performance & (Grembergen and Saul, 2001) \\
\hline & & $\begin{array}{l}\text { comparing the status with industry } \\
\text { standards for services }\end{array}$ & (Watts, 2003) \\
\hline & & $\begin{array}{l}\text { the degree of IS effect in effectiveness and } \\
\text { efficiency increase }\end{array}$ & (Martinsons et. al., 1999) \\
\hline Internal processes & Source & Growth & Source \\
\hline 1. Planning excellence & (Martinsons et. al., 1999) & 1. experts' capabilities & (Martinsons et. al., 1999) \\
\hline $\begin{array}{l}\text { The percentage of resources dedicated to planning } \\
\text { and investigating IS activities }\end{array}$ & (Martinsons et. al., 1999) & $\begin{array}{l}\text { The ratio of IS training budget to total IS } \\
\text { budget }\end{array}$ & $\begin{array}{l}\text { (Martinsons et. al., } 1999 \\
\text { Epstein and Rejc, 2005) }\end{array}$ \\
\hline The time required for planning & (Grembergen and Saul, 2001) & The degree of increase in staffs' computer & (Stewart and \\
\hline The ratio of IS planning costs to total costs & (Watts, 2003) & literacy & 2003) \\
\hline & & The ability to absorb more customers & (Stewart and Mohamed \\
\hline 2. Developing excellence & (Martinsons et. al., 1999) & & 2003) \\
\hline the percentage of resources & (Martinsons et. al., 1999) & The amount of training hours & (Watts, 2003) \\
\hline development & & Staffs' productivity & (Martinsons et. al., 1999) \\
\hline $\begin{array}{l}\text { The percentage of programs codes of which are } \\
\text { reusable. }\end{array}$ & (Martinsons et. al., 1999) & $\begin{array}{l}\text { 2. effectiveness of staff management } \\
\text { The ratio of contractor staffs to official }\end{array}$ & $\begin{array}{l}\text { (Grembergen and Saul, 2001) } \\
\text { (Watts, 2003) }\end{array}$ \\
\hline The time required for IS development & (Martinsons et. al., 1999) & permanent staffs & \\
\hline The time spent for resolving IS mistakes and errors & (Martinsons et. al., 1999) & The ratio of management staffs to all staffs & (Watts, 2003) \\
\hline $\begin{array}{l}\text { Comparing estimated time with actual time for } \\
\text { development }\end{array}$ & (Watts, 2003) & $\begin{array}{l}\text { The percentage of staffs who accomplished } \\
\text { development programs }\end{array}$ & (Grembergen and Saul, 2001) \\
\hline 3. Implementing excellence & (Martinsons et. al., 1999) & $\begin{array}{l}\text { The percentage of voluntary replacement } \\
\text { according to performance level }\end{array}$ & (Grembergen and Saul, 2001) \\
\hline $\begin{array}{l}\text { The ratio of the number of maintenance staff to total } \\
\text { staffs }\end{array}$ & (Watts, 2003) & $\begin{array}{l}\text { The percentage of staffs who received } \\
\text { rewards based on their performance }\end{array}$ & (Epstein and Rejc, 2005) \\
\hline The ratio of support budget to total budget & (Watts, 2003) & The ratio of illness per day for each person & (Watts, 2003) \\
\hline The degree of decrease in flaws and faults & (Stewart and Mohamed, 2003) & 3. researches on modern technologies & (Martinsons et. al., 1999) \\
\hline $\begin{array}{l}\text { The average time required to answer customers' } \\
\text { requests }\end{array}$ & $\begin{array}{l}\text { (Martinsons et. al., 1999; } \\
\text { Epstein and Rejc, 2005) }\end{array}$ & $\begin{array}{l}\text { the ratio of research budget to the total } \\
\text { budget }\end{array}$ & (Martinsons et. al., 1999) \\
\hline
\end{tabular}


The percentage of unplanned IS Idling

The degree of decrease in unnecessary visits

The percentage of standard infrastructures

The ratio of integrated systems to total systems

\section{The degree of improvement}

The degree of processes improvement using IT

The degree of communication improvement using IT

The degree of decision making improvement using IT

The degree of improvement in the speed of reporting

and getting feedback

The number of new products and services provided

by IT unit

\begin{tabular}{|c|c|c|}
\hline $\begin{array}{l}\text { (Martinsons et. al., 1999; } \\
\text { Epstein and Rejc, 2005) }\end{array}$ & $\begin{array}{l}\text { satisfaction degree of senior managers } \\
\text { about reports on modern technologies }\end{array}$ & (Martinsons et. al., 1999) \\
\hline (Stewart and Mohamed, 2003) & 4. organization development & (Grembergen and Saul, 2001) \\
\hline (Epstein and Rejc, 2005) & internal processes improvement & (Grembergen and Saul, 2001) \\
\hline (Epstein and Rejc, 2005) & IS renewal & (Grembergen and Saul, 2001) \\
\hline (Stewart and Mohamed, 2003) & $\begin{array}{l}\text { Adopting systems on IT standards and the } \\
\text { architecture of organization }\end{array}$ & (Grembergen and Saul, 2001) \\
\hline $\begin{array}{l}\text { (Stewart and Mohamed, 2003) } \\
\text { (Stewart and Mohamed, 2003) }\end{array}$ & $\begin{array}{l}\text { Developing the architecture plan of the } \\
\text { organization }\end{array}$ & (Grembergen and Saul, 2001) \\
\hline $\begin{array}{l}\text { (Stewart and Mohamed, 2003) } \\
\text { (Stewart and Mohamed, 2003) }\end{array}$ & $\begin{array}{l}\text { The percentage of documented and } \\
\text { measured IT processes }\end{array}$ & (Epstein and Rejc, 2005) \\
\hline
\end{tabular}

(Epstein and Rejc, 2005)

To study and analyze IS strategic management based on the balanced scorecards, the maturity model of IT balanced scorecards was used. According to IT balanced scorecards maturity model (Luftman, 2001), the maturity model of IT balanced scorecard is divided into five levels each of which has unique characteristics. These five levels are as follows:
1) initial/ad hoc process
2) committed process
3) established focused process
4) improved /managed process
5) optimized process

Table 3. The leveling base of organizations for implementation of IS strategic management based on balanced scorecards (Luftman, 2001)

\begin{tabular}{|c|c|c|c|c|c|c|}
\hline characteristics & & Level 1 & Level 2 & Level 3 & Level 4 & Level 5 \\
\hline \multirow[t]{5}{*}{ communications } & $\begin{array}{l}\text { The familiarity degree } \\
\text { of IT unit with } \\
\text { business }\end{array}$ & Minimum & Limited & $\begin{array}{l}\text { Limited to senior } \\
\text { and middle } \\
\text { managers }\end{array}$ & $\begin{array}{l}\text { Familiarity } \\
\text { extends to lower } \\
\text { levels too }\end{array}$ & Comprehensive \\
\hline & $\begin{array}{l}\text { The familiarity degree } \\
\text { of business units with } \\
\text { IT }\end{array}$ & Minimum & Limited & $\begin{array}{l}\text { Preliminary } \\
\text { familiarity }\end{array}$ & $\begin{array}{l}\text { In the organization } \\
\text { level }\end{array}$ & Comprehensive \\
\hline & $\begin{array}{ll}\text { The degree of } \\
\text { intra-organization } \\
\text { inter-organization } \\
\text { learning }\end{array}$ & $\begin{array}{l}\text { Temporary, } \\
\text { sometimes }\end{array}$ & Informal & Regular and clear & Integrated & Structured \\
\hline & $\begin{array}{ll}\text { The degree } & \text { of } \\
\text { participation } & \text { in }\end{array}$ & Temporary & Semi-structured & Structured & Institutionalized & $\begin{array}{l}\text { Beyond } \\
\text { organization }\end{array}$ \\
\hline & knowledge exchange & & & & & \\
\hline \multirow[t]{7}{*}{ Value Measuring } & $\begin{array}{l}\text { IT indicators based on } \\
\text { ITBSC }\end{array}$ & $\begin{array}{l}\text { Technical and } \\
\text { not related to } \\
\text { business }\end{array}$ & $\begin{array}{l}\text { Efficiency based } \\
\text { on cost }\end{array}$ & $\begin{array}{l}\text { Traditional, based } \\
\text { on financial issues }\end{array}$ & $\begin{array}{l}\text { Effectiveness and } \\
\text { the cost }\end{array}$ & $\begin{array}{l}\text { Extended to external } \\
\text { participants }\end{array}$ \\
\hline & $\begin{array}{l}\text { Business indicators } \\
\text { based on BSC }\end{array}$ & $\begin{array}{l}\text { Temporary } \\
\text { and not }\end{array}$ & $\begin{array}{l}\text { in functional } \\
\text { organization }\end{array}$ & $\begin{array}{l}\text { Traditional, based } \\
\text { on financial issues }\end{array}$ & Customer oriented & $\begin{array}{l}\text { Extended to external } \\
\text { participants }\end{array}$ \\
\hline & & related to IT & & & & \\
\hline & $\begin{array}{l}\text { The degree of } \\
\text { consistent }\end{array}$ & None & Minimum & $\begin{array}{l}\text { Primary } \\
\text { improvement }\end{array}$ & Too often & Repeatedly \\
\hline & $\begin{array}{l}\text { improvement of } \\
\text { indicators }\end{array}$ & & & & & \\
\hline & $\begin{array}{l}\text { Official review and } \\
\text { evaluation } \\
\text { indicators }\end{array}$ & None & $\begin{array}{l}\text { In the event of } \\
\text { problems }\end{array}$ & Officially & Officially & Repeatedly \\
\hline & The relation between & Not related & Not related & Related & Related & Business, IT \\
\hline
\end{tabular}




\begin{tabular}{|c|c|c|c|c|c|c|}
\hline & $\begin{array}{l}\text { IT indicators and } \\
\text { business }\end{array}$ & & & & & $\begin{array}{l}\text { shareholders are } \\
\text { related }\end{array}$ \\
\hline \multirow[t]{6}{*}{ Participation } & $\begin{array}{l}\text { The degree of } \\
\text { perception of IT value } \\
\text { by business }\end{array}$ & Cause of cost & As a property & As a property & As a facilitator & $\begin{array}{l}\text { As a factor in line } \\
\text { with business }\end{array}$ \\
\hline & $\begin{array}{l}\text { The role of IT in } \\
\text { business } \\
\text { planning }\end{array}$ & None & $\begin{array}{l}\text { Facilitating } \\
\text { organization } \\
\text { processes }\end{array}$ & $\begin{array}{l}\text { Facilitating } \\
\text { organization } \\
\text { processes }\end{array}$ & $\begin{array}{l}\text { A factor in } \\
\text { business strategy }\end{array}$ & $\begin{array}{l}\text { Be in alignment } \\
\text { with business }\end{array}$ \\
\hline & $\begin{array}{l}\text { The degree of } \\
\text { consistent } \\
\text { improvement in IT } \\
\text { plan management }\end{array}$ & Temporary & $\begin{array}{l}\text { Indication } \quad \text { of } \\
\text { standards }\end{array}$ & $\begin{array}{l}\text { Cohesion of } \\
\text { standards }\end{array}$ & $\begin{array}{l}\text { Improvement of } \\
\text { standards }\end{array}$ & $\begin{array}{l}\text { Cohesive } \\
\text { improvement }\end{array}$ \\
\hline & $\begin{array}{lr}\text { The degree of } \\
\text { innovation } \\
\text { entrepreneurship }\end{array}$ & No incentive & $\begin{array}{l}\text { Related } \\
\text { functional } \\
\text { organization }\end{array}$ & $\begin{array}{l}\text { Capable of risk } \\
\text { bearing }\end{array}$ & $\begin{array}{l}\text { IT managers, } \\
\text { shareholders and } \\
\text { organization }\end{array}$ & Become a norm \\
\hline & Management style & Order-based & $\begin{array}{l}\text { Common-sense-b } \\
\text { ased }\end{array}$ & Result-oriented & $\begin{array}{l}\text { Based on profit } \\
\text { and value }\end{array}$ & Relation-oriented \\
\hline & $\begin{array}{l}\text { The degree of } \\
\text { readiness for change }\end{array}$ & $\begin{array}{l}\text { Resistance } \\
\text { against } \\
\text { change }\end{array}$ & $\begin{array}{l}\text { Related } \\
\text { functional } \\
\text { organization }\end{array}$ & $\begin{array}{l}\text { Realizing need for } \\
\text { change }\end{array}$ & So much & So much \\
\hline \multirow{3}{*}{ Skill } & Staffs substitute & None & Minimum & $\begin{array}{l}\text { Related } \\
\text { functional } \\
\text { organization }\end{array}$ & $\begin{array}{l}\text { Related } \\
\text { functional } \\
\text { organization }\end{array}$ & $\begin{array}{l}\text { In the level of } \\
\text { organization }\end{array}$ \\
\hline & Education & None & Minimum & $\begin{array}{ll}\text { Related } & \text { to } \\
\text { functional } & \\
\text { organization } & \end{array}$ & $\begin{array}{l}\text { Related } \\
\text { functional } \\
\text { organization }\end{array}$ & $\begin{array}{l}\text { In the level of } \\
\text { organization }\end{array}$ \\
\hline & $\begin{array}{l}\text { Political, social and } \\
\text { trust climate }\end{array}$ & Minimum & $\begin{array}{l}\text { Based } \\
\text { exchanges }\end{array}$ & $\begin{array}{l}\text { Creating valuable } \\
\text { services }\end{array}$ & $\begin{array}{l}\text { Creating valuable } \\
\text { services }\end{array}$ & $\begin{array}{l}\text { Making valuable } \\
\text { participations }\end{array}$ \\
\hline \multirow[t]{8}{*}{ Administration } & $\begin{array}{l}\text { The degree of business } \\
\text { strategic planning }\end{array}$ & Temporary & $\begin{array}{l}\text { Planning in } \\
\text { functional level }\end{array}$ & $\begin{array}{l}\text { Intra-organization } \\
\text { planning }\end{array}$ & $\begin{array}{l}\text { In the level of } \\
\text { organization }\end{array}$ & $\begin{array}{l}\text { Integrated intra and } \\
\text { inter organization }\end{array}$ \\
\hline & $\begin{array}{l}\text { The degree of IT } \\
\text { strategic planning }\end{array}$ & Temporary & $\begin{array}{l}\text { Functional } \\
\text { tactical planning }\end{array}$ & $\begin{array}{l}\text { Focused on } \\
\text { intra-organization } \\
\text { planning }\end{array}$ & $\begin{array}{l}\text { In the level of } \\
\text { organization }\end{array}$ & $\begin{array}{l}\text { Integrated intra and } \\
\text { inter organization }\end{array}$ \\
\hline & Budget control & Cost based & $\begin{array}{l}\text { Based on cost in } \\
\text { functional level }\end{array}$ & $\begin{array}{l}\text { Based on costs } \\
\text { and investments }\end{array}$ & $\begin{array}{l}\text { Based on } \\
\text { investments }\end{array}$ & $\begin{array}{l}\text { Based on investment } \\
\text { and profit }\end{array}$ \\
\hline & $\begin{array}{l}\text { Management of IT } \\
\text { investments }\end{array}$ & Cost based & $\begin{array}{l}\text { Based on cost and } \\
\text { focused on } \\
\text { maintenance and } \\
\text { operation }\end{array}$ & $\begin{array}{l}\text { Traditional, and } \\
\text { process } \\
\text { improvement }\end{array}$ & Cost effectiveness & $\begin{array}{l}\text { Business value and } \\
\text { extended to business } \\
\text { participants }\end{array}$ \\
\hline & Committees & $\begin{array}{l}\text { Informal and } \\
\text { irregular }\end{array}$ & $\begin{array}{l}\text { Periodical } \\
\text { organization }\end{array}$ & $\begin{array}{l}\text { Clear and regular } \\
\text { relations }\end{array}$ & $\begin{array}{l}\text { Official } \\
\text { effective }\end{array}$ & Participation \\
\hline & Priority process & Reactional & Often reactional & Planned & $\begin{array}{l}\text { Planned to } \\
\text { increase value }\end{array}$ & $\begin{array}{l}\text { To increase value } \\
\text { for shareholders }\end{array}$ \\
\hline & $\begin{array}{l}\text { Architectural } \\
\text { flexibility }\end{array}$ & None & Limited & $\begin{array}{l}\text { Focused on } \\
\text { communications }\end{array}$ & $\begin{array}{l}\text { In the level of } \\
\text { organization }\end{array}$ & $\begin{array}{l}\text { In the level and out } \\
\text { of organization }\end{array}$ \\
\hline & Standards definition & None & $\begin{array}{l}\text { Defining } \\
\text { standards }\end{array}$ & $\begin{array}{l}\text { Emerging } \\
\text { organizational } \\
\text { standards }\end{array}$ & $\begin{array}{l}\text { organizational } \\
\text { standards }\end{array}$ & $\begin{array}{l}\text { organizational } \\
\text { standards }\end{array}$ \\
\hline \multirow[t]{2}{*}{ Architecture } & Used systems & $\begin{array}{l}\text { Traditional } \\
\text { like } \\
\text { accounting }\end{array}$ & Operational & $\begin{array}{l}\text { Extended to } \\
\text { facilitate business } \\
\text { process }\end{array}$ & $\begin{array}{l}\text { Revising business } \\
\text { processes }\end{array}$ & $\begin{array}{l}\text { To connect with } \\
\text { outside of the } \\
\text { organization }\end{array}$ \\
\hline & $\begin{array}{l}\text { Intra and } \\
\text { organization } \\
\text { integration }\end{array}$ & None & $\begin{array}{l}\text { Primary efforts } \\
\text { for integration }\end{array}$ & $\begin{array}{l}\text { Integration in the } \\
\text { level of } \\
\text { organization }\end{array}$ & $\begin{array}{l}\text { Integration with } \\
\text { shareholders }\end{array}$ & $\begin{array}{l}\text { Integration with all } \\
\text { shareholders }\end{array}$ \\
\hline
\end{tabular}


Six major variables of "measurement", "participation", "administration", "skill", "communication" and "architecture" and other minor variables (Table 3) were used in IT balanced scorecard maturity model. The higher (lower) scores for related variables in the selected organizations, the implementation of IS strategic management based on balanced scorecard in the organization will be higher (lower).

Since measurement means to define, document and implement IT criteria based on IT balanced scorecard and to relate IT criteria to business, some criteria such as availability of evaluation system for IT department of the organization, official revision of criteria for evaluation of IT performance were utilized in IS strategic management in the organization. Participation means IT value perception by business and improving management of IT plans. To measure this feature, such criteria as the role of IT in business strategic planning and perception of IT value by the organization as a competitive advantage have been used.

Administration means the IT strategic planning, budget control and IT investments management. To measure administration, some criteria have been considered as follows:

Defining IS vision and mission in the organization, alignment of investment priorities, incentive systems and budget control by IT scorecard.

To measure skill which means innovation, entrepreneurship and the position of IT management in decision making, such criteria as persistence of the organization on innovation and entrepreneurship, staffs' readiness for accepting changes, availability of political, social and trust climate in the organization to run IT balanced scorecard have been indicated. Communication feature means learning intra- and inter-organization. Architecture feature means the flexibility of the structure due to technology changes. To measure these features, criteria such as intra- and inter-organization integration and changes in the structure due to technology changes have been used.

\section{Research Methodology}

In this study, in terms of data collection methods, the descriptive method was used. Because in this way, the features found in the organizations can be aware. In terms of research aim, this study is applicable one which can be used for solving the problems of different companies and studying the solutions. In this study, scientific methods and procedures to define the problem, define hypotheses, data collection, classification, analysis, conclusions and recommendations are used.

Data collection of this research was performed in two field and library methods:

1) Field research: it is to get the idea of organizations which have executed information systems strategic management or information technology balanced scorecard.

2) Library research: it is used to review the literature and research theories.

Statistical population of the present study is organizations in Tehran which have executed information systems strategic management or information technology balanced scorecard.

In this research, sampling is executed using non-probability sampling (convenience sampling) and (purposive sampling) from organizations in Tehran (30 organizations).

The following hypothesis is studied and tested in this research:

"There is a significant relationship between information systems strategic management based on balanced scorecard and information systems performance.

As mentioned above, the hypothesis of the research is a null hypothesis and as a result, there is no basis for showing the direction of hypothesis.

The variables for this hypothesis are "information systems strategic management based on balanced scorecard" and "information systems performance". 
Table 4. Variables used for assessing information systems strategic management based on balanced scorecard ITBSC maturity model in this research

\begin{tabular}{ll}
\hline Features & Sub features \\
\hline Communications & The level of inter and intra organization learning \\
& Indicators based on ITBSC \\
Value measurement & Official review and evaluation of indicators \\
& The relationship between IT and business indicators \\
& The business perception of IT value \\
Participation & The role of IT in business strategic management \\
& The degree of consistent improvement of IT program management \\
& The degree of innovation and entrepreneurship \\
& Management position \\
Skill & Readiness for changes \\
& The political, social environment and trust climate \\
& Education \\
Administration & The degree of IT strategic planning \\
Architecture & Budget control \\
& IT investment management \\
& Architecture flexibility
\end{tabular}

Table 5. Variables used for assessing IT performance in research

\begin{tabular}{ll}
\hline Features & Sub features \\
\hline \multirow{3}{*}{ Financial } & Cost control \\
& Risk control \\
& Value management \\
& Planning excellence \\
& Developing excellence \\
Internal processes & Implementing excellence \\
& Improvement level \\
& Creating and retaining relation with users \\
User's satisfaction & Satisfaction level \\
& Performance level \\
& Capability of experts \\
Growth & Effectiveness of staff management \\
& Researches on modern technologies \\
& Organization development \\
\hline
\end{tabular}

\section{Validity and Reliability of Questionnaire}

By validity of questionnaire, it means the accuracy of indicators and criteria which have been produced for measuring intended phenomenon. Determining validity means answering to this question whether the research measured what it had to measure (Danaei Fard et al, 2004).

In addition to mentioned literature review, 30 experts of information systems strategic management and balanced scorecard were discussed about the veracity of variables selected for questionnaire. To measure the reliability of the questionnaire, the Cronbach's Alpha coefficient was used and the necessary corrections were applied in the questionnaire according to achieved results.

The experts' opinions suggest that Cronbach's Alpha are 0.91 and 0.92 respectively for 33 questions and 30 samples of the first questionnaire (information systems strategic management based on balanced scorecards) and 48 questions and 30 samples of the second questionnaire (information systems performance assessment), which are considered as a good rate.

The organizations' opinions suggest that Cronbach's Alpha are 0.95 and 0.96 respectively for 33 questions and 30 samples of the first questionnaire and 40 questions and 30 samples of the second questionnaire, which are considered as a good rate. 


\section{Statistical Analysis Techniques}

Since the questionnaires have been created in ordinal scale, the nonparametric statistical techniques were used in the statistical analysis. Regarding the hypothesis situation, nonparametric tests such as spearman correlation test and $\mathrm{U}$ mann withney test were used in this research.

\subsection{Correlation Test}

By the null hypothesis, it is assumed that there is no correlation. The fact is of course that explanation and interpretation of Spearman is more difficult than Pearson, perhaps as a result of data nature. When data is quantitative and is converted to qualitative data, the spearman correlation coefficient is a criterion for measuring the linear relationship between ratings (Azar, Momeni, 2001).

\subsection{Signed Test}

The goal of this test is to answer this question whether samples are chosen from "equal" contiguous society (have equal averages) or not (have different averages).

If the goal is to decide on samples drawn from two societies, the U-test, sometimes called "Wilcoxon" or "Mann Whitney" test, is used (Azar, Momeni, 2001).

Since organizations studied in this research were selected from both public and private groups, Mann-Whitney was used to compare averages for both IT performance and the level of IT balanced scorecard maturity.

\section{Hypothesis Test}

\subsection{Correlation Test}

Table 6. Hypothesis test using spearman correlation coefficient

\begin{tabular}{lccc}
\hline & PERFORM \\
\hline Spearman's rho & LEVEL & 0.71 & $* *$ \\
\hline
\end{tabular}

** Correlation is significant at the .01 level (2-tailed).

As it is shown in above table, the maturity level of ITBSC in organizations is directly related to IT performance. The

** mark shows that the hypothesis is approved at 0.99 level of confidence.

\subsection{Comparison Test between Two Public and Private Groups According to ITBSC and Performance Level}

Since both public and private organizations were used in this research, it is required to compare these two sections. On the one hand, as the ranking scale was used for this hypothesis and also samples are independent, Mann Whitney $\mathrm{U}$ test was used result of which is as Table 7.

Table 7. Mann Whitney U test for comparing public and private organizations

\begin{tabular}{ccc}
\hline & LEVEL & PERFORM \\
\hline Exact Sig. [2*(1-tailed Sig.)] & 0.54 & 0.46
\end{tabular}

Therefore, there is no significant difference between public and private groups. Because organizations have not actually and completely implemented ITBSC in their organizations.

\section{Conclusions}

According to results of the present research, it is possible to state that decrease (increase) in the level of information systems strategic management based on balanced scorecard, decreases (increases) the performance of information systems. In other words, improving level of information systems strategic management based on balanced scorecard is a basic factor effective on information systems performance. In this regard, it is concluded that non-improvement of major features effective on the level of information systems strategic management based on balanced scorecard (value measurement-administration-participation-skill-communications-architecture) leads into inactivity of ITBSC aspects (financial-growth and learning-user's satisfaction-internal processes).

The chart (1) shows that private organizations have better status in measurement and administration features, while the public organizations are in a better situation in other features (skill, communications, participation and architecture). 


\section{measurement}

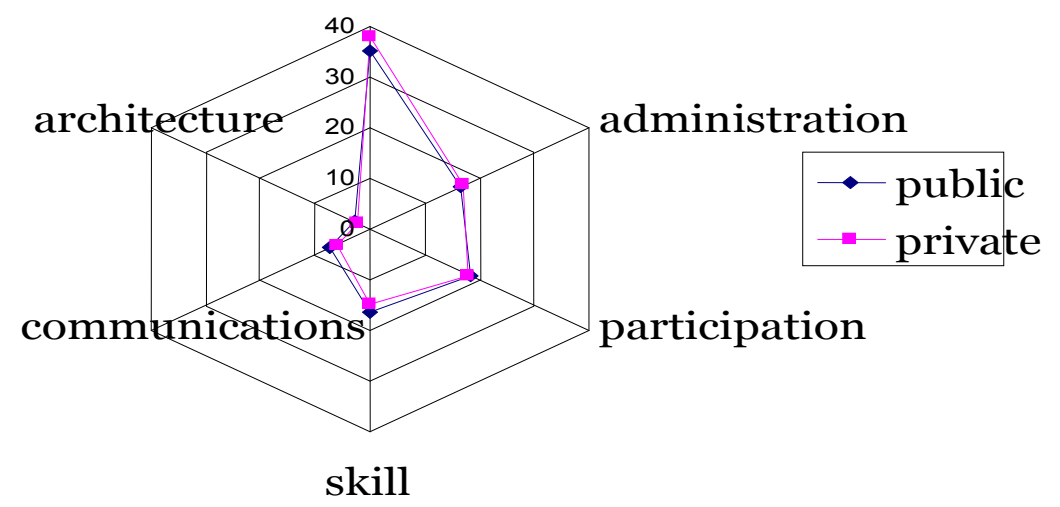

Chart 1. The comparison between features of ITBSC maturity model in public and private organizations

Also, Chart (2) compares public and private organizations in respect of ITBSC criteria. As it is shown, the private organization has better score in financial aspect, while the public organization has better score in other aspects (growth and learning, internal processes and user's satisfaction). However, the difference between public and private organizations is a little in internal processes aspect.

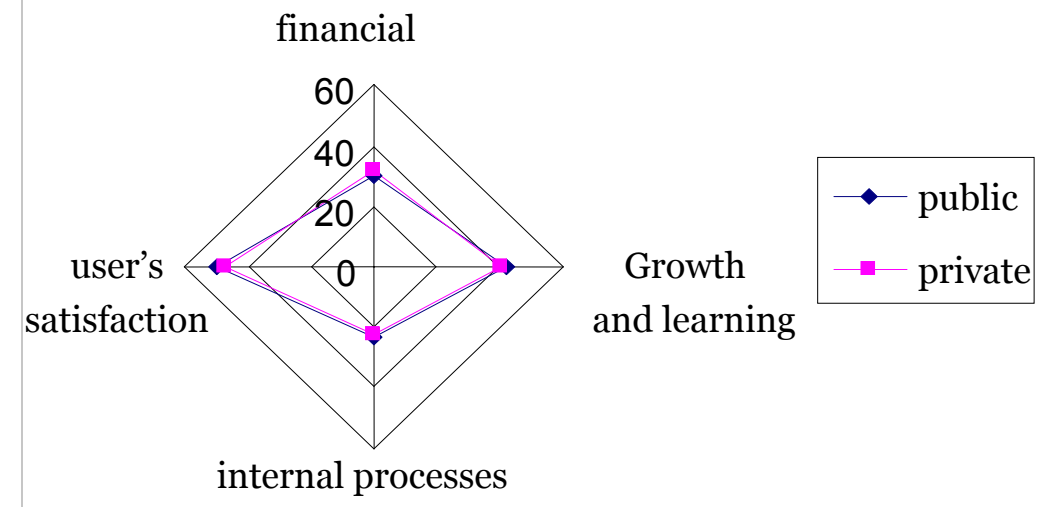

Chart 2. The comparison between aspects of ITBSC in public and private organizations

\section{Suggestions}

Following suggestions are provided for this research:

1) Changing and conducting information systems strategic management based on the results of information systems performance evaluation:

Making information systems strategies based on information systems performance results in always up-to-date strategies. Hogarth and Markridarkis (1981) refer to the fact that "a long time (for two years or more than it) forecast is obviously incorrect and inaccurate". Mintzberg (1987) declares that making strategy requires acceptance and recognition of factors which influence the future strategic direction of the organization.

According to Clark (2007), it is also indicated for information systems, because forecasting a repetitious pattern or foreseeable incidence is not the important matter in making strategies for information systems, but it is the effective factors for changing the information systems strategy to be forecasted. As it was studied in this research, information systems performance is one of these factors. 
2) Substantial reviewing of current criteria for performance evaluation:

The main subject in performance improvement is setting out and using performance criteria. Performance criteria should be the best indicator of improvement in matters related to customers, organizational operation, and financial affairs. A comprehensive set of criteria or indicators related to customers or performance requirements of organization, makes a clear ground for setting all activities in line with organizational goals. Therefore, it is required to implement a system including comprehensive criteria for performance evaluation in the organization.

3) Consistency between information technology performance evaluation system and other systems:

Basically, each performance evaluation system such as balanced scorecard should be able to coordinate and conform to other systems in use such as reward system. According to the statement "you get what you pay for", Ogden et al. (2002) states that employees responsible for objectives will try to maximize their benefits and strive to avoid punishment (Wagner and Kaufmann, 2004). This link is critical for motivation and commitment.

4) Insisting on comprehensive performance evaluation:

What many organizations use as performance evaluation is the evaluation of the program which has fundamental differences with comprehensive performance evaluation. The most important difference between program evaluation and comprehensive performance evaluation is non-generality, while, in the current competitive environment, futurism requires understanding and assisting long and short-term factors that impact on the business and the position of the organization. It means that despite of benefits of program evaluation such as making experience, valid comparison between programs and providing information, the comprehensive performance evaluation should be considered as a valuable method.

Additionally, significant concerns have been expressed regarding perceived problems in achieving congruence between the balanced scorecard and other organizational control systems. In this case (Atkinson, 2006) argues that there are different viewpoints in order to overcome difficulties such as replacement of BSC with other controls rather than compliment (Ahn,2001) and combination of the BSC with long established systems (Otley, 2001).

5) Employing committed managers and motivated staffs:

It is not easy to achieve certain qualitative and quantitative goals of the organization and requires support of managers and motivated staffs. In some aspects of balanced scorecard, such as financial aspect (value management) and growth and learning (capability), commitment and motivation of managers and staffs are broadly insisted on. Similarly, it is insisted on communications and skill features which are amongst criteria affecting balanced scorecard. That is to say, it will only be successful when the people who develop and work with them are motivated and convinced that the effort is worthwhile (Wagner and Kaufmann, 2004). In this case, there are several reasons why the commitment of the people may be low and decline over time. First, nearly two-thirds of the firms underestimate the required efforts at the beginning of a BSC project. Second, if misunderstood and not properly communicated, many executives and especially employees may perhaps consider the BSC concept another fashionable management tool that they discard. Sometimes, bad experiences with unsuccessful management methods and tools lead to a general resistance against new concepts (Wagner and Kaufmann, 2004).

6) Consistency of used balanced scorecard with organizational culture

Cultural differences affect both balanced scorecard development and its acceptability. The balanced scorecard is developed and implemented in a different way in each country. Even each job has its own culture which includes unofficial rules and laws. For instance, resistance against change included in culture of some organizations, affects the balanced scorecard. The key to good performance is to have a strong culture (Mujeeb and Ahmad, 2011).

7) Availability of performance data

Processing (collection, analysis, and interpretation) performance data and the adequate IT system knowledge is one of the challenges for effective use of BSC (Franco and Bourne, 2003). The full level of integration between performance management and other key management processes can only be activated with the support of information technology by providing data warehouses and integrated applications with business intelligence capabilities.

\section{References}

Atkinson, H. (2006). Strategy implementation: a role for the balanced scorecard? Management Decision, 44, 1441-1460. http://dx.doi.org/10.1108/00251740610715740

Azar, A., \& Momeni, M. (2001). Statistics and its application in management. SAMT: Tehran. 
Benjamin, B. M. S., \& Winston, T. L. (2001). Measuring the value of information technology in technical efficiency with stochastic production frontiers. Information and Software Technology, 43, 447-456. http://dx.doi.org/10.1016/S0950-5849(01)00150-1

Bharadwaj, G. S., Varadarajan, P. R., \& Fahy, J. (1993). Sustainable competitive advantage in service industries: A conceptual model and research propositions. Journal of Marketing, 57, 83-99. http://dx.doi.org/10.2307/1252221

Clark, S. (2007). Information Systems Strategic Management: An Integrated Approach. Routledge: UK.

Danaeifar, H., Alvani, S. M., \& Azar, A. (2004). The methodology of quantitative research in management: a comprehensive approach. Safar: Tehran.

Epstein, M. J., \& Rejc, A. (2005). How to measure and improve the value of IT. Strategic Finance, 87, 35 - 41.

Franco, M., \& Bourne, M. (2003). Factors that play a role in managing through measures. Management Decision, 41, 698-710. http://dx.doi.org/10.1108/00251740310496215

Ghaeni, E. (2006). Evaluating performance of IT governance with balanced scorecard approach in Shipping and Ports Organization of Iran. Master of IT Management, Faculty of Management, Allameh Tabatabaei University, Tehran.

Grembergen, W. V. (2000). The balanced scorecard and IT governance. Information Systems Control Journal, 2, $40-43$.

Grembergen, W. V., \& Bruggen, R. V. (1997). Measuring and improving corporate Information Technology through the balanced scorecard technique. Proceedings of the European Conference on the Evaluation of Information Technology, Delft, The Netherlands.

Grembergen, W. V., \& Saul, R. (2001). Aligning business \& IT through the balanced scorecard at a major Canadian financial group: its status measured with an ITBSC maturity model. 34TH Hawaii International on System Sciences.

Grembergen, W. V., Saull, R., \& Haes, S. D. (2003). Linking the IT balanced scorecard to the business objectives at a major Canadian financial group. Journal of Information Technology Cases and Applications.

Kaplan, R., \& Norton, D. (1993). Putting the balanced scorecard to work. Harvard Business Review, 134-137.

Kaplan, R., \& Norton, D. (1996). The balanced scorecard,translating strategy into action. Harvard Business School Press: Boston

Kaplan, R., \& Norton, D. (1996). Using the balanced scorecard as a strategic management system. Harvard Business Review: Boston

Kaplan, R., \& Norton, D. (2004). Strategy maps: converting intangible assets into tangible outcomes. Harvard Business School Press: Boston.

Keen, G.W. P. (1991). Shaping the future: business design through information technology. Boston MA: Harvard Business School Press.

Khanlari, A., \& Mohammadi, K. (2006). Evaluating the role of IT in organizations based on balanced scorecard. The third conference on information and communications.

Lee, B., \& Menon, N. M. (2000). Information technology value through different normative lenses. Journal of Management Information Systems, 16, 99-119.

Luftman, J. (2001). Assessing Business-IT Alignment Maturity, pp.105-132.

Martinsons, M. (1992). Strategic thinking about information management. The 11 the annual conference of the international association of management consultants, Toronto.

Martinsons, M., Davison, R., \& Tse, D. (1999). The balanced scorecard: a foundation for the strategic management of information systems. Decision Support Systems, 25, 71-88. http://dx.doi.org/10.1016/S0167-9236(98)00086-4

Mingfang, L., \& Richard, L. Y. (1999). Information technology and firm performance: linking with environmental, strategic and managerial contexts. Information \& Management, 35, 43-51. http://dx.doi.org/10.1016/S0378-7206(98)00075-5

Mujeeb, E. U., \& Ahmad, M. S. (2011). Impact of organizational culture on performance management practices in Pakistan. International Management Review, 7, 52-57. 
Sircar, S., Turnbow, L. J., \& Bordoloi, B. (1998). The impact of information technology investments on firm performance: a review of the literature. Journal of Engineering Valuation and cost analysis, 1, 171-181.

Stewart, R. (2002). Life cycle management of information technology (IT) projects in construction. Doctor of Philosophy, Faculty of engineering and Information Technology, Griffith University.

Stewart, R. (2007). IT enhanced project information management in construction: Pathways to improved performance and strategic competitiveness. School of Engineering, Griffith University, 1-25.

Stewart, R., \& Mohamed, S. (2003). Evaluating the value IT adds to the process of project information management in construction. Automation in Construction, 12, 407-417. http://dx.doi.org/10.1016/S0926-5805(03)00006-2

The balanced scorecard and knowledge management. Retrieved September 20, 2004, from http://www.balancedscorecard.org

Wagner, S.M., \& Kaufmann, L. (2004). Overcoming the main barriers in initiating and using purchasing-BSCs. Journal of Purchasing \& Supply Management, 10, 269-281. http://dx.doi.org/10.1016/j.pursup.2004.12.001

Watts, B. (2003). A balanced scorecard (BSC) for IT performance management. SAS Institute Australia, 1-8. Retrieved August 17, 2003, from http://cmga.org.au/proceedings/1999/watts99.pdf 